\title{
Upconversion of low-energy photons in semiconductor nanostructures for solar energy harvesting — ERRATUM
}

Eric Y. Chen, Christopher C. Milleville, Joshua M. O. Zide, Matthew F. Doty and Jing Zhang

In the original publication of this article [1], there were several errors and omissions. They are as follows:

1. Author Christopher C. Milleville's middle initial was missing and has since been updated.

2. Table 2 contained value errors. An updated version of the table is included below.

\begin{tabular}{|c|c|c|c|c|c|c|c|}
\hline & $\begin{array}{l}\text { Compatible } \\
\text { solar cells }\end{array}$ & $\begin{array}{l}\text { Absorption } \\
\text { bandwidth } \\
\text { (AB) (meV) }\end{array}$ & $A B(n m)$ & $\begin{array}{l}\text { Maximum } \\
\text { energy gain } \\
(\mathrm{meV}, \mathrm{nm})\end{array}$ & $\begin{array}{l}\text { Internal } \\
\text { UQE (\%) }\end{array}$ & $\begin{array}{l}\text { Lowest conc. } \\
\text { for observed } \\
\text { UC (suns) }\end{array}$ & Ref. \\
\hline $\begin{array}{l}\text { Homogeneously } \\
\text { doped lanthanide }\end{array}$ & $\mathrm{mc}, \mu \mathrm{c} \mathrm{Si}$ & 80 & $1450-1600$ & $\begin{array}{c}450 / 1440^{d} \\
1523 \text { to } 980 / 550^{d}\end{array}$ & $32.4 \%$ & $\sim 15$ suns & 18 and 25 \\
\hline $\begin{array}{l}\text { Core/multi-shell } \\
\text { lanthanide }\end{array}$ & $\mathrm{mc}, \mu \mathrm{cSi}$ & 350 & $1100-1600$ & $\begin{array}{c}720 / 1440^{\mathrm{d}} \\
1523 \text { to } 810 / 550^{d}\end{array}$ & $\ldots$ & $\sim 100$ & 67 \\
\hline TTA & a-Si:H, DSC & $413 / 50^{a}$ & $600 / 730-750$ & 730,700 to 520 & $35 \% c$ & $1.4,0.3$ & $22,24,27$ \\
\hline TPU & III-V & 765 & $690-1190$ & 765,1190 to 690 & $\ldots$ & 17 & 61 \\
\hline QDUC & $\begin{array}{c}\text { a-Si:H, } \\
\text { CIGS, DSC }\end{array}$ & $>700 / 800$ & $600-850 / 980$ & 700,850 to 580 & $0.002 \%$ & 1 & 56 \\
\hline
\end{tabular}

3. On page 14, the word "(theoretical)" should follow the value for TTA molecules, and the citation should read " 65 ".

4. Reference 77 should not have been included.

5. Figure 16 is the original work of the authors - the caption noting "Adapted from Ref. 72 " was incorrectly attributed.

6. The authors would like to add thanks in their acknowledgements to J. M. Cleveland, D. B. Chase, and K. R. Lennon for helpful discussions.

The authors regret these errors and omissions.

\section{REFERENCE:}

1. Chen E. Y., Milleville C. C., Zide J. M. O., Doty M. F., and Zhang J. (2018). Upconversion of low-energy photons in semiconductor nanostructures for solar energy harvesting. MRS Energy \& Sustainability, 5, E16. doi:10.1557/mre.2018.15 